\title{
当院での舟状骨偽関節に対する治療
}

$$
\begin{aligned}
& \text { 村 岡 邦 秀* 尾上 英 俊* 木 村 一 雄* } \\
& \text { 斉 田 } \text { 光 }^{*} \text { 林 } \\
& \text { 武* 野 田 大 輔* }
\end{aligned}
$$

\section{Treatment of Scaphoid Nonunion}

\author{
Kunihide Muraoka*, Hidetoshi Onoue*, Kazuo Kimura*, \\ Hikaru Saita*, Takeshi Hayashi*, and Daisuke Noda*
}

\begin{abstract}
舟状骨偽関節に対して手術治療を行い良好な経過を得たので報告する。1 1995 年〜2009 年までに手術治 療を行った舟状骨偽関節 14 例のうち 3 ヶ月以上経過観察できた 11 例を対象とした。性別は男 8 , 女 3 例 で手術時平均年齢は 34 歳であった。受傷から手術までの期間は平均 166 日で, 平均経過観察期間は 14 力 月である。手術はまず為関節部の掻爬を䯣腔内まで十分に行い，1辺のみ皮質骨を残した長方形の腸骨ブ ロックを採型しておく。次に䯣空内の陥凹部に海綿骨チップを充填し，腸骨ブロックの皮質骨側を掌側に 向けて打ち込み棒で間隙に打ち込む。最後に Acutrak または Herbert screw で内固定を行う。術後は 2 〜 週の thumb spica cast 固定を行い，適宜装具を装着させた。全例で良好に骨癒合し，疼痛や手関節 の可動域制限などの臨床症状は認めていない.
\end{abstract}

From 1995 to 2009, we treated 11 cases of scaphoid nonunions, and report treatment details due to the excellent outcome. They consisted of eight males and three females, and their mean age at operation was 34 years, ranging from 8 to 67 years. The volar approach was used. First the nonunion gap was exposed and debrided carefully into the medullary cavity, after which the corticocancellous graft obtained form the iliac crest was shaped into a rectangle slightly larger than the defective bone. After this, cancellous bone chips were filled into the medullary cavity, and the cortical side of the corticocancellous graft was driven in towards the palmar aspect with a surgical hammer. Finally, the scaphoid was internally fixed using Acutrak or Herbert screws. The mean operating time was 99 minutes, ranging from 69 to 157 minutes. Postoperatively, the patients wore a thumb spica cast for two to four weeks. All patients achieved union radiographically in 55 weeks on average, ranging from 33 to 118 weeks. No complications nor clinical symptoms were seen.

Key words : scaphoid nonunion (舟状骨偽関節), Fernandez method (フェルナンデス法), bone graft (骨移植)

\section{はじめに}

舟状骨偽関節に対する手術には様々な方法がある. 今回我々は舟状骨偽関節に対し Fernandez 法 ${ }^{1)}$ に準 じた遊離自家腸骨移植手術を行うことで良好な結果を 得たので報告する。

\section{対象と方法}

1995 年 2 月 2009 年 12 月までに当院で治療を行っ た舟状骨偽関節 14 例中 3 ヶ月以上経過観察できた 11
例（男性 8 例，女性 3 例）を対象とした。手術時平均 年齢は 34 歳（18～67 歳）で受傷から手術までの期間 は平均 166 日（84〜360日）であった。経過観察期間 は平均 14 力月（3〜47ヶ月）である. 偽関節の分類 には Filan-Herbert 分類 ${ }^{2)}$ (以下 F-H 分類) 及び, 池田ら ${ }^{3)}$ の分類を用いた。 F-H 分類は，D1：偽関節 部に変形を認めないもの，D2：偽関節部に変形を認 めるが骨硬化像が無いもの，D3：骨硬化像が有るむ の, D4：無腐性壊死と定義しており，我々の症例で は D2 が 3 例，D3 が 8 例であった。また池田らは受

* 福岡徳洲会病院整形外科 Department of Orthopaedic Surgery, Fukuoka Tokushukai Medical Centre, Fukuoka, Japan 
傷からの期間に関係なくレントゲン所見のみに基づい て分類している。それによると，線状型：転位なしか あっても $2 \mathrm{~mm}$ 未満, 襄胞型：線状型で骨折線が囊 胞状透亮像を示す，硬化・転位型： $2 \mathrm{~mm}$ 以上の転位 か硬化帯が $1 \mathrm{~mm}$ 以上と定義されており，我々の症 例では全例が硬化・転位型に分類された。部位別に分 類すると, 舟状骨腰部が 8 例, 舟状骨遠位 $1 / 3$ が 3 例であった．手術は全て掌側アプローチで行った。 ま ず偽関節部の掻爬を髄腔内まで十分に行い，生じた皮 質骨の間隙を計測し腸骨ブロックの採骨を行う。腸骨 ブロックは 1 辺のみ皮質骨を残した長方形とし間隙よ りあ少し大きいサイズに形を整えておく，次に髄腔内 の陥凹部に海綿骨のチップを充填し，採型した腸骨ブ ロックの皮質骨側を掌側に向けて, 打ち込み棒を使っ て間隙に打ち込む. 最後に Acutrak または Herbert screw で内固定を行なう（図 1 ）.

術後は $2 \sim 4$ 週の Thumb spica cast 固定を行なっ たが，その間に骨癒合が確認された 2 例を除いては, その後さらに $2 \sim 11$ 週装具を装着させた.

これらの症例について，手術時間，骨癒合と骨癒合 までの期間，および術後合併症を検討した。な搒癒 合の判定は移植骨との境界が見えなくなった時点とした.

\section{結果}

手術時間は平均 99 分であった。全例で良好に骨癒 合し，骨癒合までの期間は平均 55 日であった。疼痛 や手関節の可動域制限等の臨床症状は認めず，術後合 併症も認めていない.

症例 18 歳男性.

野球練習中に右手をついて受傷した。右手関節痛が 出現し, 疼痛が増強したため受傷 1 力月後に近医を受 診した，右手舟状骨骨折と診断され保存加療を受けた が疼痛が軽快せず，受傷 11 力月後に当科を紹介され， 右手舟状骨偽関節之診断した（図 2). F-H 分類 D3, 池田らの分類では硬化・転位型であり, 受傷後 1 年で 手術を行った。手術時間は 94 分であった。術後は 4 週 thumb spica cast 固定を行い, その後さらに2 週 装具を装着した。術後 33 日で骨癒合し, 術後 2 年の 最終調査時に疼痛や可動域制限などの臨床症状は認め ていない(図 3 ).

\section{考察}

舟状骨偽関節に対する治療には様々な方法があり,
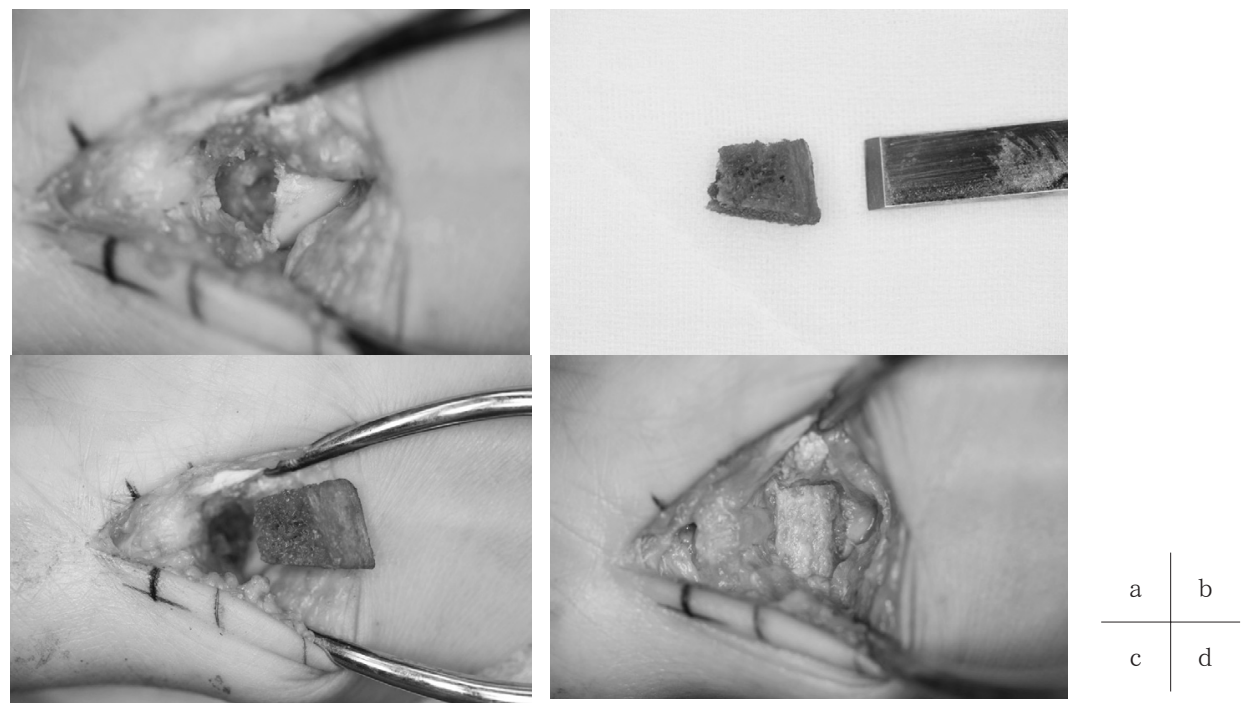

図 $1 \mathrm{a}$ ：偽関節部の掻爬を髄腔内まで十分に行う

b : 生じた皮質骨の間隙をノミで計測し腸骨ブロックの採骨を行う

c：䯣腔内の陥凹部に海綿骨のチップを充填する

$\mathrm{d}$ ：採型した腸骨ブロックの皮質骨側を掌側に向けて，打ち込み棒を使って間隙に打ち込む 


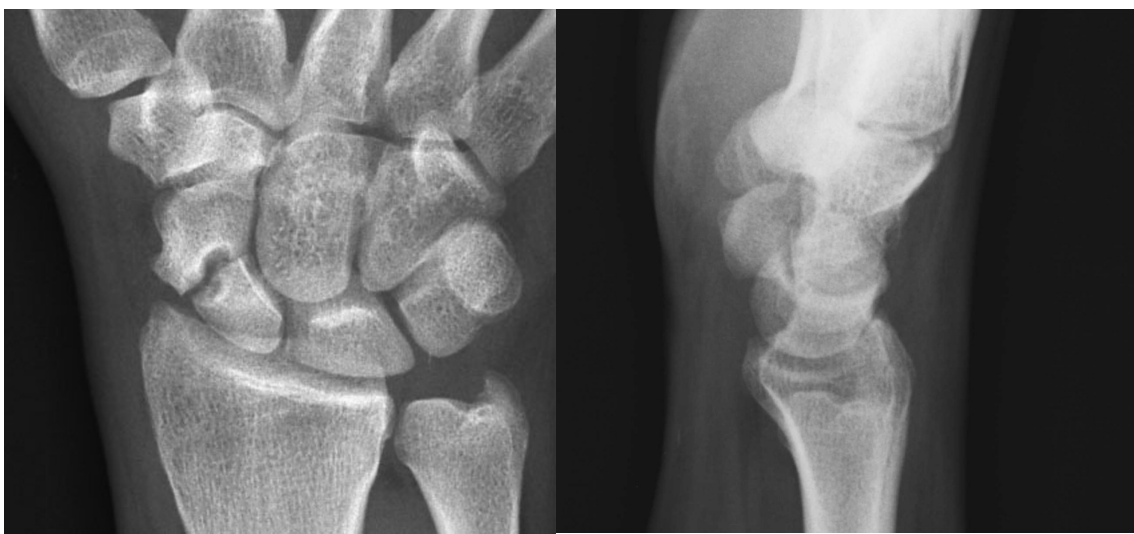

図 218 歳男性

初診時 : 舟状骨腰部に偽関節を認める

(F-H 分類：D3，池田らの分類：硬化転位型
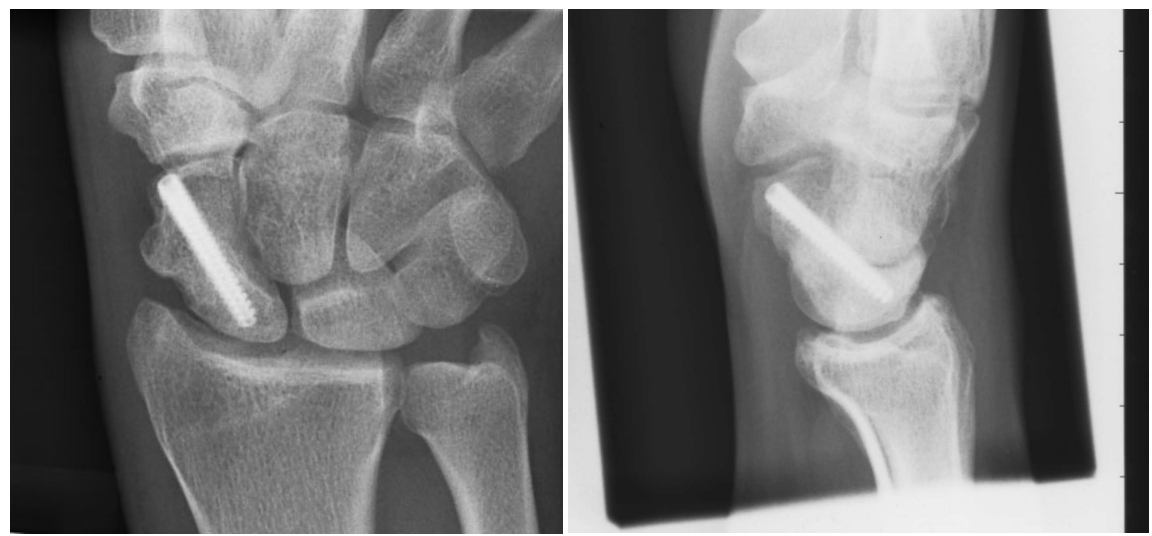

図 318 歳男性

術後 2 年：良好に骨癒合している

その適応に関してはいまだ意見が分かれている，坂本 ら $^{6)}$ は F-H 分類 D1， D2 が遊離自家骨移植，D3 が 血管柄付き骨移植の適応であるとする一方，岡田ら ${ }^{4}$ は F-H 分類 D3 であっても経皮的 screw 固定が第 1 選択であると述べている。また池田ら ${ }^{3)}$ は X 線で硬 化・転位型の所見を認めれば受傷からの期間に関わら ず遊離自家骨移植の適応であるとしている。当院では F-H 分類 D2, D3 及び池田らの分類における硬化・ 転位型に遊離自家腸骨移植手術を，F-H 分類 D1 に対 してはscrew による内固定を行ってきた。

舟状骨偽関節に対する骨移植手術は Russe ${ }^{5)}$ による 報告以降，有効な治療法として広まったが，この方法
では掌屈変形を含めた舟状骨骨長の矯正が困難であっ た。そこで Fernandez は移植骨を楔状に加工して， それを掌側から移植することにより掌屈变形を矯正し， さらに screw による内固定を追加することで外固定 期間を短縮させる手術法を報告した。我々は，この方 法に順じて舟状骨偽関節に対する遊離自家腸骨移植手 術を行ってきたが，腸骨ブロックの型にはあまりこだ わらなかった。移植骨は骨片間に生じた間隙よりも少 し大きいサイズで，1辺のみ皮質骨を残したほぼ長方 形に採型する。それを骨片間にしっかり打ち込んで移 植した後, screwによる内固定を行っている（図 4 ). 移植骨を正確な楔状に採型する方法に比べ，手技の煩 


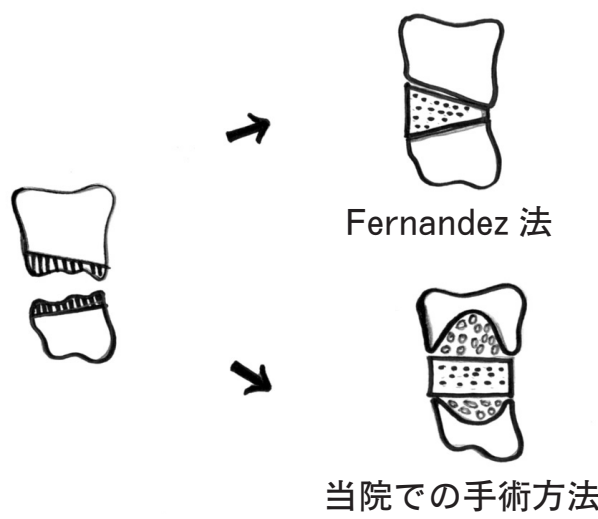

図 4 Fernandez 法之当院での手術方法

雑さがなく, 手術時間も平均 99 分と比較的短時間に する事ができた。また，この方法で舟状骨骨長の矯正 あ可能であり,さらに䯣腔内まで十分に掻爬を行って から海綿骨チップを充填することが骨癒合に有利に働 くと考えている. 今回提示した症例においても全例で 骨癒合し，疼痛や手関節の可動域制限を残した症例は 認めなかった。

我々が行ってきた長方形の移植骨を用いた舟状骨偽 関節に対する骨移植手術により，比較的簡便な手技で 確実な骨癒合が得られた。Fernandez 原法と比べて 掌屈変形に対する矯正の精密さに関しては劣るかもし れないが，舟状骨偽関節に打ける DISI 变形矯正の必
要性に関して一定の見解が得られていない現在，確実 に骨癒合が得られる我々の方法は有用な手術方法であ ると思われた。

\section{ま と め}

1. 舟状骨偽関節 11 例に対して Fernandez 法に準じ た遊離自家腸骨移植手術を行った。

2. 偽関節部を十分に搔爬する事で生じた骨内陥凹部 に海綿骨チップを充填し, 骨片の間隙に十分なサイ ズの皮質骨付きブロックを打ち込んで移植すること で良好な骨癒合が得られた。

\section{参 考 文 献}

1) Fernandez, D. L. : A technique for anterior wedgeshaped grafts for scaphoid nonunions with carpal instability. J. Hand Surg., 13-A : 733-737, 1984.

2) Filan, S. L., Herbert, T. J. : Herbert screw fixation of scaphoid fractures. J. Bone Joint Surg., 78 - B 519-529, 1996

3）池田和夫ほか：舟状骨骨折のレントゲン所見に基づい た治療方針。日手会誌，24：58-62，2007.

4）岡田貴充ほか：舟状骨遷延癒合例に対する経皮的骨接 合術の適応．日手会誌，25：907-909， 2009.

5) Russe, O. : Fracture of carpal navicular ; Diagnosis, nonoperative treatment and operative treatment. JBJS, 42A : 759-768, 1960.

6) 坂本相哲ほか：舟状骨偽関節に扮ける治療法の選択. 日手会誌，24：532-534，2008. 